\title{
Youths and Sustaining Democracy in Nigeria: Issues, Challenges and Way Forward
}

\author{
Onyido Josephine Azuka ${ }^{1, *}$, Brambaifa Anna Preye ${ }^{2}$ \\ ${ }^{1}$ Department of Educational Foundations, Faculty of Education, University of Port Harcourt \\ ${ }^{2}$ Department of Curriculum Studies and Educational Technology, Faculty of Education, University of Port Harcourt \\ *Corresponding author: azukaonyido@yahoo.com
}

Received January 10, 2019; Revised February 26, 2019; Accepted March 26, 2019

\begin{abstract}
The crux of democracy is dependent on the desires of the population which such government serves. The Youths have been identified as an essential section of any country's population because of their contribution to economic and democratic development. In the case of Nigeria, youths have participated in politics, engineer agitation for environmental protection, electoral process and civil justice which constitute aspects of the democratic experience. However, in recent times the democratic experience in the country has been threatened by violence and insecurity which have been perpetuated by youths. This study is therefore informed by the need to analyse the challenges faced in sustaining democracy in Nigeria, the impact youths have on the sustenance of democracy in Nigeria as well as solutions that can be adopted to sustain democracy in the country. The study employs a survey design approach using a structured questionnaire titled "Impact and Challenges of Youths in Sustaining Democracy" (ICYSD) for data collection and was guided by three research questions. A total of 200 youths residing in Cross rives state were sampled from 1200 youths in the Niger delta region. Data was analysed employing frequencies and percentages. The findings indicates that the primary challenge faced in sustaining democracy is illiteracy, ethnic sentiment, unemployment, poverty amongst others and that the impact of youths on the sustenance of democracy include manpower provision, voter strength, electoral violence and disruption of economic activities to mention a few. This study further reveals that through empowerment programmes, access to education, religious and ethnic tolerance and job creation, democracy can be sustained in Nigeria.
\end{abstract}

Keywords: democracy, youths, sustenance

Cite This Article: Onyido Josephine Azuka, and Brambaifa Anna Preye, "Youths and Sustaining Democracy in Nigeria: Issues, Challenges and Way Forward." American Journal of Educational Research, vol. 7, no. 3 (2019): 279-283. doi: 10.12691/education-7-3-13.

\section{Introduction}

Every country operates a system of governance, governance refers to the manner the country is governed. Scholars have identified Monarchy, Democracy, Oligarchy, Autocracy and Theocracy, as systems of governance that have been operated across the world. In recent times however, democracy has become a house hold name across the world and is increasingly being adopted by more countries across the world as such, making it one of the most commonly employed systems of governance [1]. Although the practice of democracy varies from one country to another, democracy bases its foundation on ensuring that the rights of citizens are protected while developing and running the affairs of the country through popular vote. Democracy can therefore be defined as governance that is chosen by the people for the people through an electoral procedure [2]. This implies that the democracy that is practiced in Ireland varies from that practiced in United Kingdom, United States of America, Australia to mention but a few. Throwing more light on democracy, scholars have highlighted that it is culled from the Greek language and refers to "rule by simple majority". Hence, it can be defined as the ruling of a society through an electoral process that ensures that the freedom of citizens to associate with a view to actualizing their ideals and defend and advance their interest [3]. As such principally, the task of any society is to rebuild and revitalize itself while building its own abilities, educating and mobilizing its citizens [4] which include youths, midaged and elderly and they must therefore continue to allow themselves be educated and mobilized if the true values of democracy are to be sustained through consolidation and deepening of equity, in the fabrics of any society.

\subsection{Youths}

Youths can be defined as anybody between the ages of 18 and 30 [5]. In present projections of populations, it is estimated that over one billion of the world population are youths [6]. They are the owners and leaders of tomorrow [7] Scholars have continued to buttress the importance of youths to economic and political development [8]. According to Kura [6] in the past, people were not trusting 
of the abilities of youths. This created a barrier for youths to surmount in order to attain their true potentials. However, in spite of their distrust and challenges, the contributions of the youths to societal development have continued to increase. Anasi [9] postulates that their creative abilities, labour power and orientation define the level, security and pace of development of a country.

According to Arubayi [10] they are potentially and are essentially the necessary resources worthy of investment by any nation and as such they are at the center of sustainable development of any country and any country that truly seeks to achieve meaningful national development must harness the potentials of the youths. In Nigeria, according to National population commission cited in Akinyemi \& Isiugo-Abanihe [11], it is estimated that the population of the youths is over 140 million. Their demographical significance in the Nigerian context make them valuable contributors as partners, stakeholders, organisers, entrepreneurs as well as strategic catalyst for national advancement.

In the political scene, going by the age bracket that youths are classified, they represent a significant percentage of the electorates. According to Anasi [9] they out-number the aged and the middle-aged in the society. As such, their role in the electoral process cannot be over emphasized. Khasan [12] postulates that they are the mobilizers of political revolutions and changes and this has seen them in developed countries take up political appointments. The President of France, Emmauel Macron, Prime Minister of Ireland; Leo Varadkar, Sebastian Kurz foreign minister and former President of Nigeria Nnamdi Azikiwe and many more are typical examples where youths have embraced politics and empowerment. However, proponents have highlighted the cynicism usually associated with youths regarding politics [9]. This has subsequently affected their attitude towards existing political and organizational settings thereby affecting their participation in politics [7]. In developing countries this experience is even worsened by unemployment, lack of educational opportunities, poverty and corruption. These conditions can be particularly seen in the Nigerian democratic system.

\subsection{Democracy in Nigeria}

Nigeria, situated in the western part of the African continent is the most populous country in Africa with more than 150 million inhabitants [13]. The Nigerian democratic experience is a peculiar one. Once described as one of the strongholds of military dictatorship in Africa, the country has become an exemplary figure of the democratic practice in the African continent $[1,14]$.

Prior to the military interruption of the democratic system of government, the country gained its political independence in 1960 under a democratic parliamentary system which has since evolved into presidential system of democracy that has produced four republics spanning several years. The cultural diversity of the Nigerian population has presented distinctive socio-political challenges for the country's political scene and has seen nepotism; ethnicity, tribalism and corruption gear its ugly head in a country with over 350 distinct ethnic groups.

These sentiments has been passed down across generations and has seen youths easily swayed into violence as a result of misgivings towards another tribe that have been stirred by political and religious figures. As a result of this the country is constantly faced with fear of ethnic and religious clashes, insecurity posed by unemployed youths, protest by youths, terrorist attacks, militancy activities such as oil pipeline explosions and kidnapping by youths to mention a few.

\section{Statement of the Problem}

History records that the efforts of the youths in the emancipation of Nigeria from colonial rule and the continued sustenance of democracy cannot be overlooked. According to Chika \& Onyene [15] the participation of youths in the democratic process in Nigeria can be traced back to $1920 \mathrm{~s}$ when Nigerian youths started establishing local newspapers such as the "Lagos Daily Newspaper" by Herbert Macaulay and the "Nigerian Daily Times" by Richard Barrow and Adeyemo Alakija in 1925 and 1926 respectively. These newspapers were instrumental in raising the consciousness of the Nigerian youths and in 1934, a political party known as Nigerian National Democratic Party was floated by Herbert Macaulay [13] and ever since politically oriented groups such as the Arewa Youth Consultative Forum (AYCF), TIV Youth Organization (TYO), Ijaw Youth Congress (IYC) to mention a few have continued to raise and agitate for issues that affect the political landscape of the nation. These agitations have led to the passage of the not too young to run bill by the House of Assembly with a view to encouraging youth participation in governance. The nascent democratic process in Nigeria is however, not without its challenges, there is still widespread electoral subversion, political violence and ethnic related agitation in the country that are perpetuated by youths under the instructions of political leaders and elders [1]. As such, using the youths as weapons against the growth of democracy in the country.

The recently held presidential election in 2019 supports this proposition and saw wide spread cases of political violence and ethnic related agitation across the country prior to the elections by youths. These actions further threaten the sustenance of democracy in the country and must be tackled if the country is to experience true democratic dividends and national growth. This paper therefore, seeks to analyse the role of youths in sustaining democracy in Nigeria.

\section{Study Objectives}

The purpose of this research is the following objectives were addressed:

1. To ascertain the challenges of sustaining democracy in Nigeria.

2. To determine the impact of youths on sustaining democracy in Nigeria.

3. Proffer solutions to sustaining democracy in Nigeria.

\section{Research Questions}

The following research questions guided the study:

1. What are the challenges of sustaining democracy in Nigeria? 
2. What role do youth have on sustaining democracy in Nigeria?

3. What efforts are necessary for sustaining democracy in Nigeria?

\section{Methodology}

The study adopts a survey design approach that sought the opinions of youths across the Niger-Delta region

(I) Scope of the study

The study was carried out in the Niger Delta region which comprises of Abia, Delta, Rivers, Akwa Ibom, Cross River, Bayelsa, Imo, Ondo and Edo states. The study purposely selected youths residing in Cross Rivers State because of its level of socio-economic development as well as the population of youths residing in this state. The study focused on youths residing in Calabar town that were from each of the 36 states in the country.

(II) Study Population

The population for the study is made up of students, corps members, workers. In order to capture every geo-political zone, two hundred participants were selected from the population employing stratified sampling technique and random sampling was employed to get the participants that took part in the research.

(III) Sample of the Study

For the purpose of the study, a sample size of two hundred respondents was drawn up from the population comprising 114 males and 86 females aged between 20 to 30 years.

\section{(IV) Instrumentation}

The research instrument was titled "Impact and Challenges of Youths in Sustaining Democracy" (ICYSD) questionnaire fashioned for data collation and to allow participants state their opinions about these issues. The instrument was divided into four sections titled "A-D". Section "A" addressed the bio data of the participants, while sections "C-D" addressed the opinion of respondents on the impact and challenges of youths in sustaining democracy in Nigeria by asking three open-ended questions.

(V) Data Analysis

The data collated and recorded for the study were analyzed using descriptive statistics, frequency and percentages.

\section{Results and Analysis}

Upon analysis of the data collected the following results were obtained as presented below:

Table 1. Bio-data of Respondents

\begin{tabular}{|llll|}
\hline Variable & & F & $\%$ \\
Sex & Male & 114 & 57.00 \\
& Female & 86 & 43.00 \\
Geographical Zone & 20-25 years & 106 & 53.00 \\
& 26-30 years & 94 & 47.00 \\
& North Central & 22 & 11.00 \\
& South West & 40 & 20.00 \\
& North East & 30 & 15.00 \\
& South South & 20 & 10.00 \\
Total & North West & 44 & 22.00 \\
& South East & 44 & 22.00 \\
& & 200 & 100.00 \\
\hline
\end{tabular}

Research Question 1: What are the challenges of sustaining democracy in Nigeria?

Table 2. Scores by percentage of challenges of sustaining democracy in Nigeria in ranking order

\begin{tabular}{|clccc|}
\hline S/N & ITEMS & $\mathbf{N}$ & $\mathbf{F}$ & $\mathbf{\%}$ \\
\hline 1 & Illiteracy & 200 & 120 & 60 \\
2 & Ethnic sentiments & 200 & 108 & 54 \\
3 & Unemployment & 200 & 108 & 54 \\
4 & Environmental degradation & 200 & 104 & 52 \\
5 & Poverty & 200 & 100 & 50 \\
6 & Insecurity & 200 & 70 & 35 \\
7 & Bad Governance & 200 & 62 & 31 \\
8 & Religious sentiments & 200 & 58 & 29 \\
9 & Gender Bias & 200 & 56 & 28 \\
10 & Corruption & 200 & 46 & 23 \\
11 & Drug/alcohol abuse & 200 & 4 & 21 \\
12 & Educational access & 200 & 40 & 21 \\
13 & Over population & 200 & 40 & 20 \\
14 & Desperate political leaders & 200 & 34 & 17 \\
15 & False teaching in place of worship & 200 & 28 & 12 \\
16 & Marginalization & 200 & 26 & 14 \\
17 & Cult activities & 200 & 24 & 13 \\
\hline
\end{tabular}

The table above (Table 2) indicates the score by percentage of challenges to sustaining democracy in ranking order and establishes that illiteracy is the most common and prominent among these challenge with a percentage of $60 \%$ followed by ethnic sentiments $(54 \%)$. From the table (Table 2) it can be deduced that the least identified challenge to sustaining democracy in Nigeria is Cult activities (12\%).

Research Question 2: What impact do youth have on sustaining democracy in Nigeria?

Table 3. Percentage score or impact of youth on sustaining democracy in ranking order

\begin{tabular}{|clccc|}
\hline S/No & ITEM & N & F & \% \\
\hline 1 & Labour force & 200 & 124 & 62 \\
2 & Mobilizers & 200 & 118 & 59 \\
3 & Voting strength & 200 & 88 & 44 \\
4 & Resource control Agitations & 200 & 74 & 37 \\
5 & Insecurity & 200 & 68 & 34 \\
6 & Civic Unrest & 200 & 66 & 33 \\
7 & Disrupt economic activities & 200 & 26 & 13 \\
8 & Electoral violence & 200 & 36 & 18 \\
9 & Vote Selling/buying & 200 & 34 & 17 \\
10 & Discourage foreign investment & 200 & 28 & 14 \\
11 & Impact national development & 200 & 28 & 14 \\
12 & Create religious crisis & 200 & 26 & 13 \\
13 & Escalate unemployment & 200 & 26 & 13 \\
\hline
\end{tabular}

The table above (Table 3) establishes that the commonest impact of youths in sustaining democracy in Nigeria is their contribution to the labour force with $62 \%$ and their ability to mobilize other citizens for the electoral process. While the least scored is their impact in escalating unemployment in the country $(13 \%)$ as an impact on sustaining democracy.

Research Question 3: What efforts are necessary for sustaining democracy in Nigeria? 
Table 4. Percentage score or effort necessary for sustaiing democracy in ranking order

\begin{tabular}{|clccc|}
\hline S/No & ITEMS & N & F & \% \\
\hline 1 & Empowerment programme for youths & 200 & 108 & 56 \\
2 & Corrupt free administrations & 200 & 106 & 52 \\
3 & Ensuring access for citizens to education & 200 & 104 & 52 \\
4 & Ensuring employment opportunities & 200 & 103 & 52 \\
5 & Functioning Judicial system & 200 & 76 & 38 \\
6 & Provision of basic social amenities & 200 & 70 & 34 \\
7 & Advocating religious tolerance & 200 & 42 & 22 \\
8 & Press Freedom & 200 & 40 & 20 \\
9 & Training/ equipping of Security agents & 200 & 40 & 20 \\
10 & Violence free elections & 200 & 38 & 19 \\
11 & Free and fair elections & 200 & 36 & 18 \\
12 & Advocating ethnic tolerance & 200 & 32 & 16.5 \\
13 & Functioning anti-corruption agencies & 200 & 30 & 15 \\
14 & Good governance measures & 200 & 30 & 15 \\
15 & Enlightenment campaigns for youths & 200 & 26 & 13 \\
\hline
\end{tabular}

The table above (Table 4) establishes that organizing empowerment programmes for youths will immensely affect the sustenance of democracy in Nigeria (56\%) and enlightenment campaigns for youths was highlighted as having the least impact on sustenance of democracy (13\%)

\section{Discussion of Findings}

\section{Research Question one}

The study establishes that illiteracy, ethnic sentiments, unemployment, poverty, bad governance, gender bias among others are challenges in sustaining democracy in Nigeria. This opinion is supported by the studies of various scholars who highlight that a significant amount of Nigerian youths fail to enroll in schools annually [16]. This therefore agrees with the identification by the study that illiteracy significantly challenges the sustenance of democracy as it instigates ethnic sentiments, increase unemployment amongst others. This argument agrees with the proposition by Chukwuemeka \& Aghara [17] who highlight that due to marginalization, denial of social rights and environmental degradation have continued to threaten the sustenance of democracy in Nigeria through agitations. Furthermore, the studies of Elegbeleye [18] is in agreement with the findings of the research question one and proposes that inadequate social amenities, corrupt administrations, unemployment and poor educational standards have posed dangers to the sustenance of democracy in Nigeria. As such it can deduced that the challenges of sustaining democracy in Nigeria is multifaceted in nature and hence must be tackled employing a multidimensional approach.

\section{Research Question Two}

The study establishes that the youths through their activities as labour force, mobilizers for elections, voting strength, agitations for resource control, insecurity (Kidnapping, cultism, armed robbery), electoral violence and disrupting economic activities (pipe line vandalism) amongst others impact the sustenance of democracy in Nigeria. This finding is in agreement with the assertion by
Akinyemi \& Isiugo-Abanihe [11] who opines that youths are instrumental in the growth of any economy because of their benefit to the labour force and electoral strength. Furthermore, Okafor [19] posits that the participation of youths in crime threatens the stability of Nigeria's nascent democracy because of the impact it has on foreign investment, employment and national development.

\section{Research Question Three}

The study identified empowerment programmes, access to education, employment opportunities and religious tolerance amongst others as measures that can be employed to sustain democracy in Nigeria. These findings by research question one are in agreement with the proposition by Mutiba [20] who asserts that "education is the primary conduit for value formation". In addition, Awogbenle \& Iwuamadi [21] highlights that empowerment of its populace is essential tool for the societal and national development of any country.

\section{Conclusion}

This paper has sort to critically analyse the impact of youths on sustaining democracy in Nigeria. Emphasis was placed on the youth because of the economical and electoral value youths play in the society. The study has established that youths affect the investment opportunities, security, pace of development and electoral system of any country. These political and religious leaders have sort to exploit for their benefit which has consequential implications for the sustenance of democracy. This consequently led to these questions been asked to determine the challenges faced in sustaining democracy, the impact of youths on the sustenance of democracy in the country and the solutions that can be employed to sustain democracy in the country.

The findings from these questions indicate that:

- Illiteracy, ethnic sentiments, unemployment, poverty, bad governance, gender bias among others challenges the sustenance democracy in Nigeria.

- Youths through their activities as labour force, mobilizers for elections, voting strength, agitations for resource control, insecurity (Kidnapping, cultism, armed robbery), electoral violence and disrupting economic activities (pipe line vandalism) amongst others impact the sustenance of democracy in Nigeria.

- Empowerment programmes, access to education, employment opportunities and religious tolerance amongst others as measures that can be employed to sustain democracy in Nigeria.

\section{References}

[1] Adeosun, A. B. (2014). Democracy and democratic consolidation in Nigerian fourth republic: Issues and challenges. Journal of Humanities and Social Science (IOSR-JHSS) Vol, 19, 05-10.

[2] Almond, G.A.; Powell, G.B.; Strom, K. \& Dalton, R.J. (eds) (2000), Comparative Politics Today: A World View. Singapore: Pearson Education, Inc. 
[3] Akindele, R.A. (2003). Civil Society, Good Governance and the Challenges of Regional Security in West Africa. Ibadan: Vantage Pub. Ltd.

[4] Gberevbie, D. E. (2014). Democracy, democratic institutions and good governance in Nigeria. Eastern Africa Social Science Research Review, 30(1), 133-152.

[5] Igbo, H. I., \& Ikpa, I. (2013). Causes, Effects and Ways of Curbing Youth Restiveness in Nigeria: Implications for Counselling. Journal of Education and Practice, 4(6), 131-137.

[6] Kura, K.H. (2008) "Youth Participation in National Development: Opportunities and Challenges" Paper presentation at a 2-Day International Conference on Nigerian Youth and National Development Organized by The Centre for Democratic Research and Training (CDRT), Bayero University, Kano. Retrieved online from [https://www.researchgate.net/publication/273634371_Youth_and National_Development_Opportunities and_Challenges].

[7] Onyekpe, N. (2007). Managing youths at election. The Constitution: A Journal of Constitutional Development 7 (1): 76-87.

[8] Ahmed, H. (2014). The socio-economic and political impacts of youth bulge: The case of Sudan. Journal of Social Science Studies, 1(2), 224-235.

[9] Anasi, S. N. (2010). Curbing youth restiveness in Nigeria: The role of information and libraries. Library philosophy and practice, $388,1-7$

[10] Arubayi, D. (2015). Youth in Development: Understanding the Contributions of the National Youth Service Corps (NYSC) to Nigeria's National Development (Doctoral dissertation, The University of Manchester (United Kingdom))

[11] Akinyemi, A. I., \& Isiugo-Abanihe, U. C. (2014). Demographic dynamics and development in Nigeria. African Population Studies, $27(2), 239-248$
[12] Khashan, H. (2016). Youth and Revolution in the Changing Middle East, 1908-2014. Middle East Quarterly, 23(1), 7.

[13] Omoiya, S. (2012). An Historical Appraisal of Nigerian Democratic Experience. Research on Humanities and Social Sciences Vol 2, No.9.

[14] Ette, M. (2013), The press and democratic consolidation in Nigeria: Prospects and challenges. Retrieved on 11th November, 2013 from http://eprints/hud/ac.uk/id/eprints/18259.

[15] Enueme,C.. P \& Onyene, V. (2010) Youth restiveness in the Niger Delta of Niger: Implications for education and leadership. European Journal of Social Sciences. 18 (2), 286-296.

[16] Adekola, P. O., Allen, A. A., Olawole-Isaac, A., Akanbi, M. A., \& Adewumi, O. (2016). Unemployment in Nigeria; A Challenge of Demographic Change?. International Journal of Scientific Research in Multidisciplinary Studies ISROSET, 2(5), 1-9.

[17] Chukwuemeka, E \& Aghara (2010) Niger Delta youth restiveness and socio-economic development of Nigeria. Educational Research and Reviews, 5(7), 400-407.

[18] Elegbeleye, O.S. (2005). Recreational facilities in schools: A panacea for youth's restiveness. Journal of Human ecology, 18 (2) 93-98.

[19] Okafor, E. E. (2011). Youth unemployment and implications for stability of democracy in Nigeria. Journal of sustainable Development in Africa, 13(1), 358-373.

[20] Mutiba, B.G. (2011). Inculcating values the Need of the Hour: Youth Restiveness for National Peace, Transformation Development/

[21] Awogbenle, A. C., \& Iwuamadi, K. C. (2010). Youth unemployment: Entrepreneurship development programme as an intervention mechanism. African Journal of Business Management, $4(6), 831-835$

(C) The Author(s) 2019. This article is an open access article distributed under the terms and conditions of the Creative Commons Attribution (CC BY) license (http://creativecommons.org/licenses/by/4.0/) 